Prace Literackie LVIII

Wrocław 2018

https://doi.org/10.19195/0079-4767.58.28

\author{
SŁAWOMIR BOBOWSKI \\ ORCID: 0000-0001-5309-3691 \\ Uniwersytet Wrocławski
}

\title{
Polskie „westerny”
}

Wystarczy zajrzeć do Leksykonu gatunków filmowych Marka Hendrykowskiego, by dowiedzieć się, że „film kowbojski” był gatunkiem, który zmieniał się i ewoluował. Uchodzący niegdyś za arcygatunek, został zdemitologizowany w latach siedemdziesiątych XX wieku. Poza klasycznym westernem konstytutywne elementy jego poetyki (dynamiczna akcja, czarno-biały schemat świata przedstawionego, charakterystyczna sceneria itp.) adaptowano wielokrotnie: „nie tylko z myślą o tzw. śpiewających westernach i kowbojach i końskich operach, lecz również dla potrzeby innych kinematografii" . Przykładem mogą być jego europejskie odmiany: spaghetti western, eastern (swoiste repliki westernu realizowane w Europie Środkowej i Wschodniej, między innymi w Polsce) czy Ersatzwestern (imitacje westernu produkowane przez kinematografię NRD).

Jak wynika z tego wstępu, również w polskiej kinematografii przydarzyły się próby westernowe, które jednak nie opierają się na pieczołowitym odtworzeniu sztafażu gatunku, lecz na aplikacji jego głębokich struktur. Oto moja lista ,polwesternów": Ogniomistrz Kaleń (reż. Ewa i Czesław Petelscy, 1961), Zerwany most (reż. Jerzy Passendorfer, 1962), Droga na zachód (reż. Bohdan Poręba, 1961), Wilcze echa (reż. Aleksander Ścibor-Rylski, 1968), Prawo i pięść (reż. Edward Skórzewski, Jerzy Hoffman, 1964), Południk zero (reż. Waldemar Podgórski, 1970), Róża (reż. Wojciech Smarzowski 2011).

Tematyka westernu związana jest z wydarzeniami historycznymi na Dzikim Zachodzie w drugiej połowie XIX wieku, jego akcja rozgrywa się w okresie kolonizacji i stabilizowania się życia na terenach zachodnich stanów USA i obejmuje takie istotne fenomeny, jak walki z Indianami, wojna secesyjna, budowa kolei transkontynentalnej, walka z przestępczością, gorączka złota, hodowla bydła, konflikty obszarników z drobnymi farmerami itp. Przestrzeń westernowa bywa

${ }^{1}$ M. Hendrykowski, Leksykon gatunków filmowych, Poznań-Wrocław 2001, s. 173. 
przeważnie atrakcyjna, obejmuje efektowne plenery Dzikiego Zachodu, jego rozległe równiny i prerie, skaliste wąwozy itp.

Wszystkie wskazane przeze mnie ,polskie westerny” wykazują istotne analogie wobec czasoprzestrzennych parametrów westernu oryginalnego. Ogniomistrz Kaleń, Zerwany most i Wilcze echa to swoista trylogia bieszczadzka, akcja poszczególnych jej części rozgrywa się w romantycznych „westernowych” pejzażach Bieszczad (w filmie Passendorfera bohaterowie jeżdżą konno, noszą przy pasach pistolety) podczas walk toczonych przez wojsko Polski Ludowej z oddziałami Ukraińskiej Powstańczej Armii. Konflikt polsko-ukraiński o Bieszczady może do pewnego stopnia przypominać sytuację wypierania z Dzikiego Zachodu jego rdzennych mieszkańców. Z kolei Droga na zachód już tytułem przywołuje na myśl topos westernowy. Zwłaszcza słynną powieść Alfreda Bertrama Guthriego pod takim samym polskim tytułem (tytuł ang. The Way West, 1949), chociaż to skojarzenie - oczywiście - jest oczywiste tylko w naszych czasach, ponieważ w roku realizacji filmu powieść Guthriego nie była jeszcze znana polskim czytelnikom (polskie wydanie 1968) ${ }^{2}$. Ale przecież analogie z westernem nasuwają się podczas oglądania filmu Bohdana Poręby w sposób nieodparty. Właśnie kończy się wojna, emerytowany maszynista Walczak, wraz z przypadkowym pomocnikiem, ma za zadanie poprowadzić pociąg $\mathrm{z}$ amunicją i eskortą na front przez tereny, na których wciąż grasują niedobitki hitlerowskiej armii, niemieccy dywersanci i szabrownicy. Podczas walk ginie młody pomocnik maszynisty i wszyscy żołnierze konwojujący transport, ale maszynista doprowadza pociąg do miejsca przeznaczenia. Czasoprzestrzeń jest więc dynamiczna, brakuje jej stabilizacji, „kolonizatorzy” (Polacy) wypierają ludność rdzenną (niemiecką), akcja ma charakter przygodowy, jest bohater, który niemal zupełnie w pojedynkę ocala sprawę, a wiele scen rozgrywa się w westernopodobnej scenerii Szklarskiej Poręby i Jagniątkowa.

Prawo i pięść można uznać za najbardziej westernową opowieść filmową na tle całej polskiej kinematografii. Jej akcja rozgrywa się na autentycznym polskim „Dzikim Zachodzie”3, czyli na Ziemiach Odzyskanych już po ich zdobyciu i tuż przed ich nowym zasiedleniem. Właśnie nadjechali osadnicy ze wschodniej Polski, czekają na możliwość wprowadzenia się do poniemieckich domostw, ale toczy się jeszcze walka z bandami szabrowników, w której wyróżnia się samotny obrońca prawa, reprezentant nowych władz — Kenig, grany przez Gustawa Holoubka. Niektóre sceny do żywego przypominają sytuacje z Dzikiego Zachodu (na przykład strzelaniny), ballada Krzysztofa Komedy ze słowami Agnieszki

${ }^{2}$ W 1967 powstał Zachodni szlak — filmowa wersja utworu Guthriego w reżyserii Andrew V. McLaglena.

${ }^{3}$ Znamienny ma tytuł ważna książka Beaty Halickiej poświęcona osadnictwu na Ziemiach Odzyskanych: Polski Dziki Zachód. Przymusowe migracje i kulturowe oswajanie Nadodrza 19451948, Kraków 2015. 
Osieckiej ma smak i klimat arcywesternowy, a krytycy w okresie premiery filmu wprost pisali — i słusznie - o ,polskim westernie”.

Z kolei Potudnik zero i Róża to filmy z akcją umieszczoną w końcówce wojny i na początku czasu pokoju na terenach Mazur, wprawdzie geograficznie niebędących dla Polaków zachodem, ale w okresie powojennym funkcjonujących jako przestrzeń liminalna. „Kolonizatorami” byli Polacy z różnych stron Polski, zwłaszcza jednak wygnańcy ze wschodnich jej terenów przyłączonych do ZSRR, a „Indianami” byli Niemcy czy też niemieccy Mazurzy, którzy nie chcieli czy nie umieli się spolonizować. W pierwszym z wymienionych utworów wiosną 1945 roku zdemobilizowany porucznik Ludowego Wojska Polskiego i jego dwaj współpracownicy próbują tworzyć tymczasowe struktury administracyjne oraz zaprowadzić spokój i zorganizować normalne życie w pewnej mazurskiej miejscowości, której mieszkańcy są terroryzowani i zastraszani przez bandytów. Miejscowi mieszkańcy początkowo odnoszą się z nieufnością do trzech „opiekunów", ale to właśnie ci ostatni wyzwalają ich spod opresji rabusiów, płacąc nawet życiem. O filmie Smarzowskiego będzie mowa później.

$$
* * *
$$

Opowieści z Dzikiego Zachodu można ujmować jako utwory historyczne. Jednakowoż z ich historycznością jest niemały problem. Bo przecież ,prawda historyczna nie zawsze była i jest wartością cenioną przez producentów, reżyserów, scenarzystów. Wręcz przeciwnie, wielu z nich świadomie »fikcjonalizuje« świat przedstawiony swych filmów, ubarwiając go albo upraszczając, zależnie od artystycznej lub ideowej wizji" ${ }^{4}$. Grzechy westernów wobec prawdy historycznej są liczne, na przykład retuszowanie, idealizacja portretów postaci historycznych, dowódców, polityków czy wodzów indiańskich, zniekształcanie zdarzeń historycznych (na przykład przyczyn i przebiegu, a także skutków bitew). Łukasz Plesnar pisze o przyczynach takich zjawisk: „Decydowały względy narracyjne, stereotypowa wizja Zachodu, rozpowszechniona wśród kinowej publiczności, albo świadoma chęć mitologizowania świata przedstawionego westernu" ${ }^{\text {. We- }}$ sterny odbiegały też od prawdy historycznej „na poziomie scenerii, scenografii, kostiumów, rekwizytów itp."

Trudno się dziwić westernowi, że lekceważył muzę Clio, skoro był instrumentem mityzowania obrazu świata, medium z istoty swej właśnie mityzującym. Jak w naszej historii kultury estetycznej historyczne powieści przygody Henryka Sienkiewicza. Ale przecież — słusznie konstatuje Plesnar — niezależnie od owego zaprogramowania „westerny można, a czasem nawet należy, traktować jako filmy historyczne. Wszak relacjonują one proces zdobywania Dzikiego Za-

\footnotetext{
${ }^{4}$ Ł.A. Plesnar, Twarze westernu, Kraków 2009, s. 18.

${ }^{5}$ Ibidem, s. 19.

${ }^{6}$ Ibidem.
} 
chodu, odwołując się do wielu ważnych wydarzeń z dziejów Stanów Zjednoczonych. Zwłaszcza dla publiczności amerykańskiej utwory tego rodzaju osadzone są w żywej historii" "T. Tylko że nie należy wymagać od westernu obiektywności historycznej, tak jak nie można jej żądać od historycznej powieści przygody typu sienkiewiczowskiego.

Analogicznie ma się sprawa z „polskimi westernami”. Chociaż trzeba zaznaczyć, że proporcje między obiektywnością ujęcia historycznego tematu a subiektywnym, mityzującym, propagandowym nachyleniem są w każdym z nich odmienne. Najwierniejszym wobec naukowych, historycznych ustaleń obrazem jest $R o ́ z ̇ a-z$ tej oczywistej przyczyny, że film ten powstawał w wolnej, demokratycznej Polsce. Nie brakło oczywiście pośród odbiorców ludzi niezadowolonych z wizji historii wykreowanej przez Smarzowskiego, ale przecież i do najtęższych monografii historycznych zawsze można sformułować jakąś krytykę. Ponadto na korzyść reżysera przemawia stanowczo fakt, iż był niepokojony zarówno przez głosy krytyczne z lewej, jak i prawej strony politycznej sceny. Trzeba też zauważyć, że z „westernów” zrealizowanych w PRL-u żaden nie jest jakoś wyjątkowo na bakier z Historią, dzięki temu że ich autorzy nie wchodzą w szczegóły historyczne i że koncentrują się na losach bohaterów niebędących postaciami historycznymi oraz na przygodzie. Szczęśliwie wszystkie one pod względem estetycznym, dramaturgiczno-stylistycznym prezentują się nieźle, a niektóre nawet wyśmienicie, na przykład Prawo i pięść, Ogniomistrz Kaleń czy Zerwany most.

Południk zero nie zasługuje na ostrą krytykę, ale jest jednak wyrazistą, zrealizowaną bez skrępowania propagandówką. Jej prosty przekaz brzmi mniej więcej tak: komunistyczne państwo polskie było dla Mazurów jak matka i przygarnęło ich do swojej piersi. Nie ma tego ideologicznego aromatu w Prawie i pięści, w którym autorom udało się stworzyć sytuację niemal czysto westernową, a więc uniwersalną, archetypiczną: przesiedlenia są faktem, z którym nie ma sensu polemizować (jak nie było sensu polemizować z cywilizacją narzucającą Indianom swoje rygory), istotna jest tylko obrona zasadniczych wartości. Natomiast spośród trylogii bieszczadzkiej najmniej uczciwie wobec muzy Clio wypadły Wilcze echa, o których Tadeusz Lubelski napisał zupełnie słusznie w swojej Historii kina polskiego, że „zapożyczały z westernowej konwencji jedynie zewnętrzne akcesoria: obraz mężczyzn, konno i z bronią, walczących z sobą w rozległych plenerach bieszczadzkich. Nie zadbano jednak o jakiekolwiek uwiarygodnienie skomplikowanej materii fabularnej, którą był realny konflikt na polsko-ukraińskim pograniczu" ${ }^{8}$. Nieco inaczej - uczciwiej - ma się sprawa podejścia do materii historycznej w Ogniomistrzu Kaleniu i Zerwanym moście.

Podstawę scenariusza filmu Petelskich tworzyła powieść Jana Gerharda Euny w Bieszczadach (pierwsze wydanie 1959), bardzo popularna w PRL-u, wielokrot-

\footnotetext{
${ }^{7}$ Ibidem, s. 21.

8 T. Lubelski, Historia kina polskiego. Twórcy, filmy, konteksty, Katowice 2009, s. 278-279.
} 
nie wznawiana, a ze względu na „walory” ideologiczno-propagandowe zalecana przez władze państwowe do wykorzystywania w edukacji szkolnej jako lektura obowiązkowa. Pisarz, odwołując się do przeżyć własnej biografii (w latach 1945-1952 był żołnierzem Wojska Polskiego, między innymi dowódcą 34 Pułku Piechoty i w tej randze uczestniczył w walkach $z$ UPA), ukazał w powieści zmagania wojska Ludowej Polski z oddziałami powstańców ukraińskich i współdziałającymi czasem z nimi oddziałami Armii Krajowej. Powieść była próbą oddania skomplikowanej sytuacji polityczno-społecznej okresu tuż po wojnie na południowo-wschodniej ścianie Polski — w Bieszczadach. Próbą wszakże bardzo zideologizowaną i nierzetelną pod kątem jej relacji wobec prawdy historycznej i politycznej.

W filmie polskie oddziały wojska ludowego walczą z grupami UPA, których wspomagają, ze względów taktycznych, żołnierze WIN-owskiego i NSZ-owskiego podziemia. Starcia są gwałtowne i krwawe. Stroną agresywniejszą są głównie banderowcy, których jest więcej niż Polaków, znają świetnie teren i mogą liczyć na wsparcie miejscowej ludności. Są okrutni i bezwzględni. Kadry filmowe eksponują wisielców kołyszących się na stokach Halicza, a polscy żołnierze wzięci do niewoli są traktowani potwornie - barbarzyńsko torturowani i ścinani toporem w makabrycznym nazistowskim obrzędzie. Znęcaniu się na żołnierzach towarzyszy dzikie skandowanie oprawców: „Bandera! Bandera!”. W innej scenie nacjonaliści ukraińscy zabawiają się urządzaniem polskim kilku żołnierzom swoistego danse macabre. Nie wystarczy im, że biedni wojacy stoją na polu minowym, dlatego ku większej uciesze strzelają im pod nogi, aby chłopcy „tańczyli”.

Jeśli zestawimy ten obraz walk polsko-ukraińskich z naukowymi opisami starć w Bieszczadach, na przykład historyka Grzegorza Motyki, to nieuchronnie doznamy odczucia, iż klimat owych ekranowych zmagań przywołuje raczej rzeź wołyńską, a nie pojałtański polsko-ukraiński konflikt o Bieszczady. Rzeź na Wołyniu, Pokuciu i Podolu była w PRL-u tematem absolutnie zakazanym, więc można domniemywać, że Petelscy po prostu skorzystali z możliwości realizacji w ogóle jakiegokolwiek filmu o stosunkach polsko-ukraińskich i opowiedzenia w nim w sposób zawoalowany o potwornościach kresowych z okresu od lutego 1943 do lutego 1944 roku. Według historyków OUN (Organizacja Ukraińskich Nacjonalistów) i jej zbrojne ramię UPA były z obu stron — polskiej i ukraińskiej — mitologizowane. Po stronie ukraińskiej wielu widziało w nich jedynie szlachetne organizacje broniące Ukraińców przed przymusowymi przesiedleniami. Z kolei po stronie polskiej istnieje tendencja do ujmowania działań obu organizacji jako bandyckich, skoncentrowanych na zadaniu mordowania Polaków, będącego w Bieszczadach — w tejże wizji — prostą kontynuacją rzezi na Wołyniu ${ }^{9}$. Krótko mówiąc, wizerunek żołnierzy UPA w filmie Petelskich, a jeszcze

9 G. Motyka, W kręgu „Łun w Bieszczadach”: szkice z najnowszej historii polskich Bieszczad, Warszawa 2009, s. 48. 
bardziej w powieści Gerharda, jest nadmiernie przyczerniony. Ale oprócz tego nie ma w tym filmie tak licznych i rażących wypaczeń historii jak w Łunach w Bieszczadach. Można odnieść wrażenie, że czasy walk z UPA zostały ukazane przez polską parę autorów filmu jakby bez komunistycznego ideologicznego nachylenia, a jeśli nawet je odkrywamy, to jednak stwierdzamy, że nie jest jaskrawe, nie jest nachalne ${ }^{10}$.

Podobne pozytywne odczucie wywołuje, jako film zaskakująco mało zideologizowany i dość uczciwy wobec historii, Zerwany most — znakomity utwór przygodowy, oparty na dłuższym opowiadaniu Romana Bratnego pt. Śniegi płyna (1961), ze świetnie uformowanym profilem westernowym, niepozbawiony prawdy psychologicznej, socjologicznej i kulturowej. W dużym stopniu także dzięki grze aktorskiej Tadeusza Łomnickiego, wcielającego się w główną postać filmu — porucznika i inżyniera Mosura, wykonawcy wyroku na ostatnim upowskim watażce. Rzecz dzieje się w Bieszczadach, w dwóch planach czasowych — teraźniejszym, tuż po wojnie, kiedy Mosur przyjeżdża w góry do pracy jako inżynier, i przeszłym, kiedy działa w Bieszczadach jako żołnierz wojska polskiego walczącego z oddziałami UPA. Dostaje wówczas do wykonania niezwykle trudne zadanie: ponieważ zna doskonale język ukraiński, ukraińskie obyczaje, strukturę i sposoby działania upowców, ma dostać się w ich szeregi jako wysłannik działaczy UPA z Zachodu, wziąć udział w brutalnych akcjach przeciwko żołnierzom polskim i w ten sposób całkowicie uśpić czujność banderowców, aby potem zlikwidować ich dowódcę, wspomnianego ostatniego prowidnyka (granego przez Mieczysława Voita). Tym samym przyczynić się do całkowitego zakończenia działań wojennych. Zadanie zostaje wykonane, ale po wojnie, gdy porucznik przyjeżdża do Bieszczad jako inżynier, oskarża się go o współpracę z UPA. Na szczęście ocalałe dokumenty ratują mu życie i honor. Ten piękny film, wcale nienajeżony ideologią komunistyczną, nie jest także antyukraiński. Grzegorz Motyka pisze w cytowanej książce poświęconej powieści Gerharda Łuny w Bieszczadach, że Bratny też nie był zbyt rzetelny wobec faktów historycznych, gdy pisał Śniegi płyna, ale Passendorferowi udało się ominąć polityczno-ideologiczne manowce ${ }^{11}$.

$$
* * *
$$

Cytowany wcześniej Plesnar, przedstawiając sylwetkę Andrzeja Keniga z Prawa i pięści, wspomina, że konstrukcja głównych bohaterów klasycznych westernów powinna zawierać zespół charakterystycznych cech. Odtwórca pierwszoplanowej roli jest zazwyczaj ,sprawiedliwy i uczciwy, nie tylko wobec innych, ale i samego

10 S. Bobowski, Tematyka ukraińska w powojennym polskim filmie fabularnym do 1989 roku, „Studia Filmoznawcze” 2016, nr 37, s. 151-178.

${ }^{11}$ Ibidem, s. 164-166. 
siebie, samotny, energiczny, silny i bezkompromisowy" ${ }^{\prime 2}$. Kowboje, szeryfowie, łowcy nagród, żołnierze, zwiadowcy, zawodowi rewolwerowcy, jako najczęściej występujący w filmach przygodowych rozgrywających się na Dzikim Zachodzie, dodatkowo wyposażeni są w stałe atrybuty: dobro, honor, i niezależność ${ }^{13}$. Życie najczęściej przemierzają w pojedynkę. Warto przypomnieć też klasyczny pomysł Roberta Warshowa, według którego protagonistą westernu jest Człowiek Zachodu, stanowiący najważniejszy element gatunku; bohater ten jest samotny, melancholijny, doświadczający samotności organicznej, zbliżającej go do doskonałości; do przemocy, do zadawania śmierci jest zmuszony (stąd częsty deficyt porozumienia z kobietą); żyje w zgodzie z kodeksem honorowym (jego główne azymuty aksjologiczne to strzec sprawiedliwości, ładu, porządku, walczyć zawsze jak lew, a nie jak lis; jest człowiekiem bez pracy, nomadą, istotą wolną ${ }^{14}$.

Wszyscy bohaterowie „polwesternów” jakoś przypominają herosów z Dzikiego Zachodu. Budzą sympatię swoją przyzwoitością, dzielnością, zdolnością do ofiary, poświęcenia. Wszyscy stosują przemoc wymuszoną na nich, jeśli zabijają, to w obronie najwyższych wartości, samemu zresztą się narażając na utratę życia. Bywają wśród nich też tacy, którzy przypominają ów skreślony przez Warshowa romantyczno-egzystencjalny portret westernowego samotnika.

Petelscy stworzyli — pisał Stanisław Ozimek — „postać barwną, mającą w swym rodowodzie zarówno pewne cechy Costerowskiego Dyla Sowizdrzała, Sienkiewiczowskiego Kmicica, jak i współczesnego żołnierskiego wygi, który lubi wypić, ma powodzenie u kobiet, czasem chętnie powojuje, a przecież liczy dni, kiedy wróci do cywila" 15 . W istocie Kaleń (w ogromnym stopniu dzięki aktorstwu Wiesława Gołasa) jest bardzo jasnym punktem filmu. To typ realistyczny i jednocześnie silnie zindywidualizowany, czego skutkiem jest między innymi piękny heroizm i tragizm, gdy w finale ginie od kuli swoich, osłaniając swym ciałem dziecko ukraińskie. Ale też koncepcja protagonisty jest tym, co różni istotnie Ogniomistrza Kalenia od westernu. Zwłaszcza jego śmierć — w przeciwieństwie do filmów z Dzikiego Zachodu, w których bywa nadmiernie fotogeniczna — została ukazana bez upiększeń, bez optymistycznych retuszów. Gdy w znakomitym westernie Martina Ritta pt. Hombre (USA 1967) John Russell, „biały Indianin” (porwany w dzieciństwie przez Apaczów i wychowany wśród nich), grany przez Paula Newmana, ginie w finale za grupę tchórzliwych białych, to jeden $\mathrm{z}$ umierających od kuli Russella bandziorów pyta na sekundę przed zgonem: „Jak on miał, do cholery, na imię?!". W westernie bohater wygrywa, a jeśli nawet przegrywa, to $\mathrm{z}$ fasonem i optymistycznym akcentem. Tymczasem Kaleń, ranny i pół-

${ }^{12}$ Ł.A. Plesnar, Konwencje westernowe w „Prawie i pięści” oraz ,Wilczych echach”, „Kwartalnik Filmowy" 2016, nr 95, s. 140.

13 Stownik filmu, red. R. Syska, Kraków 2006, s. 187.

${ }^{14}$ Ł.A. Plesnar, Twarze westernu, s. 16.

15 S. Ozimek, Film fabularny, [w:] Historia filmu polskiego, red. J. Toeplitz, Warszawa 1980, s. 119. 
przytomny budzi się wśród wrogów w chacie z ukrywającymi się ukraińskimi kobietami i dziećmi, właśnie atakowanej przez polskich żołnierzy i ginie od ich kul, zasłaniając dziecko ukraińskie. Nie ma w tej ponurej scenie niczego atrakcyjnego. Jej jedyne piękno w postaci heroizmu prostego żołnierza przez nikogo nie zostanie zauważone. I o to właśnie chodziło Petelskim, o złożenie hołdu prostym, zwykłym, nieznanym żołnierzom, zaświadczającym nie raz na wojnie, że istnieją wartości ponadnarodowe, ponadpolityczne.

Kenig z Prawa i pięści, doskonale zagrany przez Gustawa Holoubka, przypomina Gary'ego Coopera, na co wskazał między innymi Tadeusz Lubelski, nie tylko dlatego, że pokonuje „w brawurowym finale, niczym Gary Cooper we $W$ samo potudnie (High Noon reż. Fred Zinnemann, USA 1952), czterech przeciwników po kolei"16, ale również dlatego, że to człowiek gorzko doświadczony (były więzień obozu), melancholijny, samotny intelektualista. Jednak charakterystykę bohatera westernowego sformułowaną przez Warshowa najściślej wciela Tadeusz z Róży (w koncertowym wykonaniu Marcina Dorocińskiego). Jest on człowiekiem Zachodu. Ale - oczywiście - nie w sensie dosłownym, geograficzno-kulturowym. Zachód Warshowa to metafora rzeczywistości archetypicznej. Ważna jest w tym kontekście jego definicja z czasów, które western sławił, definicja świata, w którym bohater westernowy działa, się udziela. Jest to miejsce liminalne, kresowe - pogranicze (Frontier), gdzie dochodzi do pojawienia się Girardowskiego „odróżnorodnienia"17, gdzie panuje chaos, gdzie dzikość, pierwotność ścierają się z cywilizacją albo z nowym porządkiem. Ani „dzikość”, pierwotność sama w sobie (tu - w przybliżeniu: przywiązanie Mazurów do tradycji), ani „cywilizacja” albo jakikolwiek nowy nieuchronny porządek sam w sobie (tu: nowy ład polityczny, nowe granice) nie tworzą ideału. Ideał znajduje się pośrodku, pomiędzy bohater, który jest niezależny od nowego porządku oraz od dzikości odchodzącej, jest ponad tymi dwoma żywiołami, ale jednocześnie ma cechy obu. Tadeusz jak prawdziwy jeździec znikąd — przybywa z krainy „idealnej”, którą jest Armia Krajowa, i przywraca właściwy ład. Ustawia rzeczy na odpowiednich miejscach. Jego sposób analizowania, definiowania i porządkowania rzeczywistości pochodzi z krainy bezpaństwowej, bezideologicznej. Z tej samej, z której wywodzą się motywacje szeryfa z W samo potudnie, Russella z Hombre, Shane'a z Jeźdźca znikąd (Shane, reż. George Stevens, USA 1953) czy Niesamowitego jeźdźca Clinta Eastwooda (Pale Rider, USA 1985). Z krainy ludzkich fundamentalnych wartości — nieważne, czy transcendentnej, czy doczesnej proweniencji.

Oczywiście Tadeusz zadaje ciosy, zadaje śmierć. Ale aplikowanie przemocy przez westernowego protagonistę, w odpowiednim momencie, kiedy sytuacja absolutnie tego wymaga, kiedy akt przemocy staje się spotęgowanym do maksimum wy-

16 T. Lubelski, Historia kina polskiego. Twórcy, filmy, konteksty, Katowice 2009, s. 278.

17 R. Girard, Początki kultury, przeł. M. Romanek, Kraków 2006. 
razem systemu wartości protagonisty, jest dla westernu podstawowe ${ }^{18}$. W takiej perspektywie przemoc widziana jest jako dominanta gatunkowa westernu, posłużenie się nią ,jest nieodzownym ostatecznym rozwiązaniem podstawowych problemów. Gwałt działa na sposób magiczny, a z nim łączą się inne akcenty, na przykład etyka zemsty [...]. W kategoriach akcji, emocji i moralności przemoc rozwiązuje wszystkie problemy i napięcia" ${ }^{19}$.Tadeusz zwycięża, ocala swój świat wartości i wartości Róży, tak pięknie ucieleśniający się w ich — platonicznej niemal — miłości. W planie pragmatycznym, w planie konieczności marksistowsko-darwinistycznym zwycięża połowicznie: po kilku latach wraca z zesłania i, choć jest bardzo wyniszczony, to przecież jednak triumfalnie zabiera z byłego gospodarstwa Róży, zajętego teraz przez repatriantów ze wschodu, jej córkę, którą na prośbę umierającej Mazurki pojął za żonę, aby ją w ten sposób ocalić od wywózki i od prześladowań ze strony komunistów. Jak w klasycznym westernie bohater zostaje nagrodzony kobietą za swoje bohaterstwo, a jego odejściu od wrażej przestrzeni chaosu towarzyszy dyskretnie triumfalna muzyka - trochę westernowa, wariacja na temat motywu z Prawa i pięści.

\section{Bibliografia}

Bobowski S., Tematyka ukraińska w powojennym polskim filmie fabularnym do 1989 roku, „Studia Filmoznawcze" 2016, nr 37, s. 151-178.

Girard R., Poczq̨tki kultury, przeł. M. Romanek, Kraków 2006.

Halicka B., Polski Dziki Zachód. Przymusowe migracje i kulturowe oswajanie Nadodrza 19451948, Kraków 2015.

Hendrykowski M., Leksykon gatunków filmowych, Poznań-Wrocław 2001.

Lubelski T., Historia kina polskiego. Twórcy, filmy, konteksty, Katowice 2009.

Motyka G., W kręgu „Łun w Bieszczadach”: szkice z najnowszej historii polskich Bieszczad, Warszawa 2009.

Ozimek S., Film fabularny, [w:] Historia filmu polskiego, red. J. Toeplitz, Warszawa, 1980, s. 23-40.

Plesnar Ł.A., Konwencje westernowe w „Prawie i pięści” oraz „,Wilczych echach”, „Kwartalnik Filmowy” 2016, nr 95, s. 138-150.

Plesnar Ł.A., Twarze westernu, Kraków 2009.

Stownik filmu, red. R. Syska, Kraków 2006.

\section{Polish ,westerns”}

\section{Summary}

A few Polish movies are quite peculiar from the point of view of the genre. In their style and construction, they are based on the formula of the western pattern. It is worth pointing out that these

18 Warshow pisał: „Scena przemocy musi nadejść we właściwym czasie i zgodnie z właściwymi sobie prawami — w przeciwnym razie traci sens. [...] W rzeczywistości to wcale nie gwałt znajduje się w »centrum westernu «, tylko pewne wyobrażenie człowieka, sposób bycia, który najdobitniej wyraża się poprzez akt przemocy", cyt. za: Ł.A. Plesnar, Twarze westernu, s. 17.

${ }^{19}$ Ibidem. 
films are quite good. There is some evidence that the formula of the Wild West story possesses a some timeless and universal vigor. In my essay I have analyzed Polish westerns such as Ogniomistrz Kaleń by Ewa and Czesław Petelscy (1961), Jerzy Passendorfer's Zerwany most (1962), Bohdan Poręba's Droga na zachód (1961), Aleksander Ścibor-Rylski's Wilcze echa (1968), Edward Skórzewski's and Jerzy Hoffman's Prawo i pięść 1964), Waldemar Podgórski's Południk zero (1970), and the famous picture Róża, by Wojciech Smarzowski (2011). All theseworks display some elementsof western staffage, but mostimportantly they contain the genre's characteristics and its deep structures, that is liminal space (Frontier), uncertain time of chaos, some fundamental values in danger, the passive attitude of society, an anti-hero and, of course, the PROTAGONIST - a lonely, heroic, tragic individual, representing the world of ideals.

Keywords: western, species, surface structure of the species, deep structure of the species 